\title{
Taxation of income from tourists' accommodation: case of Romanian boarding houses
}

\author{
Doina Păcurari, Ph.D, „Vasile Alecsandri” University of Bacau, Romania
}

\begin{abstract}
This paper presents the main aspects regarding taxation of income which the boarding houses' owners get from tourists' accommodation services. Whether they unfold the activity as legal person or obtain receipts as natural person, the boarding houses' owners must pay tax to the budget. The tax calculation, term of payment, submission of tax declaration, these are some issues approached in this paper. The level of taxation affects accommodation tariffs and so their competitiveness. The fiscal optimization represents a very important aspect for business administration, irrespective of size of the economic entity.
\end{abstract}

\section{Keywords}

Accommodation services, tourist boarding houses, agro-tourist boarding houses, tax, regulations

\section{JEL Codes: K34, M21}

\section{Introduction}

Although the economic crisis affected world-wide tourism, it still remains a service sector with a high potential for rally and growing. The special attention which the states pay to the tourism is reasoned by its influence to the economy, but also by its social and environment effects. The tourism contribution to the EU GDP is estimated by the Directorate General for Enterprise and Industry to be more than $5 \%{ }^{1}$. Considering also the related sectors, the tourism generates more than $10 \%$ of the EU GDP. The tourism also gives rise to employment, the number of employees in EU tourism industry being estimated between 12 and 14 million of persons, with a number of 2.3 million employees only in tourist accommodation sector ${ }^{2}$.

Taxes and fees from tourism represent an important budgetary resource. Besides profit tax and income tax, like direct taxes, the value added tax and the local taxes and fees, such as accommodation fee, are added. By taxation of income from this important activity sector, the citizens could benefit by better public services, the taxes and fees collected from service providers being used for the financing of public expenses ${ }^{3}$. Even if in this approach an augmentation of taxation is justified, it was proven that this solution is not beneficial for tourism anywhere in the world ${ }^{4}$. First of all, a higher taxation discourages this activity

\footnotetext{
${ }^{1}$ European Commission, DG Enterprise and Industry, http://ec.europa.eu/enterprise/sectors/tourism/

${ }^{2}$ Eurostat (2011), Europe in figures - Eurostat yearbook 2011, p.342

${ }^{3}$ Gooroochurn, N., \& Sinclair, M. T. (2005), Economics of Tourism Taxation: Evidence from

Mauritius, Annals of Tourism Research, Vol.32 (2), p.483

${ }^{4}$ Durbarry, R. \& Sinclair, M. T. (2000), Tourism Taxation in the UK, portal: Articulos de revistas Universidad de Sevilla, p.10
} 
sector $^{5}$. Second of all, a larger taxation than in other countries determines the decrease of respective country amenity as a destination for foreign tourists.

The majority of the tourist accommodation providers are small-sized. The big companies are not very numerous. Therefore, the taxation of small entities is important also for the state and for the contributors.

\section{Recent trends in tourist accommodation services in Romania}

The establishments for tourist accommodation are grouped in several categories such as: hotels, motels, inns, tourist boarding houses, agro-tourist boarding houses, hostels, tourist villas, chalets, camping sites, houselet-type units, and so on. The boarding houses are most numerous from the total of functional tourist accommodation establishments $(45.2 \%)^{6}$. On this account we consider that the boarding houses typify the small entities' category wherefore we want to present the taxation rules.

According to the National Institute of Statistics (NIS) ${ }^{7}$, the tourist boarding houses are establishments of tourist reception having a capacity of up to 20 rooms, in rural area, with a maximum of 60 places, which offer special designed spaces for the tourists' accommodation. According to the same reference, the agro-tourist boarding houses are establishments of tourist reception having an accommodation capacity of up to 8 rooms. Both types of establishments can operate in the owner's house or in independent establishment and must provide, besides the accommodation facilities, conditions for meals' preparing and serving for tourists in spaces properly designed.

The evolution of the accommodation capacity of Romanian boarding houses, of number of tourists' arrivals and of the overnight stays, during 2007-2011, is presented in Figure 1.

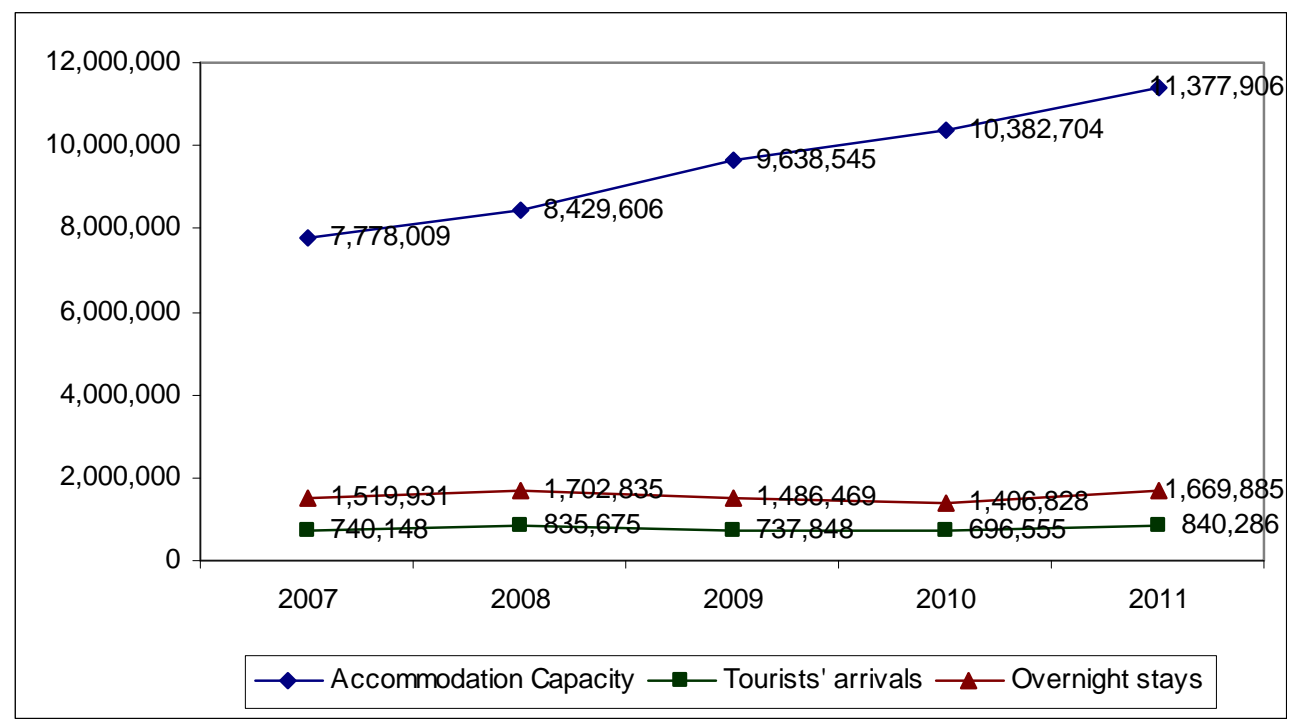

Figure 1. The evolution of the main indicators regarding tourist accommodation in boarding houses during 2007-2011

Source: NIS, www.insse.ro

\footnotetext{
${ }^{5}$ Dwyer, L., Forsyth, P., \& Papatheodorou, A. (2011), Economics of Tourism, Contemporary Tourism Reviews, p. 11

${ }^{6}$ NIS (2012), Romanian Tourism - Statistical Abstract 2012, p.20

${ }^{7}$ NIS (2010), Statistical Yearbook 2010, chap. Tourism, p.2
} 
As the figures in Figure 1 show, the accommodation capacity has grown significantly during the analysed period, from 7.778 thousands to 11.378 thousands of places. But the tourists' arrivals and the overnight stays have registered small variations, remaining around 750 thousands of tourists, and 1.550 thousands of overnight stays respectively. Consequently, the net use indices of the tourist accommodation capacity have registered small values. For instance, in 2011, the net use index of tourist accommodation capacity in tourist boarding houses was $15.5 \%$ and $13.8 \%$ in case of agro-tourist boarding houses ${ }^{8}$.

The services offered by the hotels and others tourist accommodation establishments, in 2008, represented $21.2 \%$ of the services mainly rendered to the population (as incomes, including VAT). In 2009 and 2010, this percentage decreased to $20.4 \%$. Comparatively, the weight of restaurants' service increased from $32.3 \%$ in 2008 to $36.4 \%$ in 2009 , and then slowly decreased to $35.3 \%$ in $2010^{9}$.

\section{The tourist accommodation services - legal forms of developing the economic activity}

The boarding houses' owners can develop their economic activity as natural persons (if tourist accommodation spaces are in their personal houses) or as legal persons.

If they operate as natural persons, the incomes from tourist accommodation services are considered, from a fiscal point of view, as incomes from independent activities or as incomes from the grant of the use of goods, depending of accommodation capacity of the boarding house.

If they operate as legal persons, there are two possibilities of registration: as a commercial company, required to pay the profit tax, or as a micro-enterprise, required to pay the tax on incomes of micro-enterprises.

Consequently, tourist or agro-tourist boarding house, as economic entity, is subject of taxation depending on its status. For certain categories the tax is influenced by the expenses made during the fiscal period, and for others it is not. The expenses with energy and water, staff costs, the expenses with capital or inventory depreciation, these are some of the most important expenses corresponding to the provision of accommodation services.

Hereinafter, we present the main regulations regarding taxation, applicable for the economic entities belonging to the above mentioned categories.

\section{Taxation of income from tourist accommodation services in compliance with Romanian fiscal regulations}

The Romanian Fiscal Code ${ }^{10}$ regulates, at national level, the main taxes and fees, including the profit tax and the income tax. This regulatory document establishes the rules for computing, payment and declaring these taxes due to the state budget.

For the presentation of these main regulations regarding taxation, we consider an agro-tourist boarding house whose incomes in $\mathrm{N}$ fiscal year were 50,000 m.u.. We point out that in Romania the fiscal year coincides with the calendar year. All the mentioned incomes are considered to be achieved from the tourist accommodation services. The expenses corresponding to these incomes were 30,000 m.u.. We presume that all these expenses obey the regulations in order to be deducted in taxable profit computation.

We consider the following possible situations:

\footnotetext{
${ }^{8}$ NIS (2012), Romanian Tourism - Statistical Abstract 2012, p.38

${ }^{9}$ NIS (2010), Statistical Yearbook 2010, chap. Domestic trade and market services, p.4

${ }^{10}$ Romanian Fiscal Code (2003), adopted by Low no.571/2003, published in Official Gazette, Part I, no. $927 / 23.12 .2003$
} 
A) the boarding house is registered as legal person (commercial company) required to pay the profit tax;

B) the boarding house is registered as micro-enterprise;

C) the boarding house's owner develops its economic activity as authorized natural person.

\section{Case A: The boarding house is registered as legal person required paying the profit tax}

As a Romanian legal person, other than micro-enterprise, the entity due the profit tax irrespective of the effective turnover, number of employees or other indices.

The foreign legal persons also due the profit tax if they carry out activity through a permanent office in Romania, or in an association with or without legal personality, or if they achieve incomes from/or in connection with immovable property located in Romania.

The profit tax rate is $16 \%$ and the computation basis is the taxable profit, calculated as difference between taxable incomes and deductible expenses during the fiscal period. The profit tax is computed quarterly, based on incomes and expenses cumulated from the beginning of the year. The tax declaration and payment are settled also on a quarterly basis, on or before the $25^{\text {th }}$ of the month that follows the quarter for which the tax is computed. After the fiscal year is closed, the annual profit tax must be computed and the eventual differences must be regulated.

The anticipatory payments system is also applied in Romania but only by the banking companies. This system demands the calculation of anticipatory payments as a fourth of the profit tax of the previous year, multiplied with the consumer price index. Anticipatory payments for the first three quarters of the year must be made. After the annual profit is settled, the eventual difference to the tax due must be calculated and paid on or before March $25^{\text {th }}$ of the next year.

If the contributors register losses, their recovering can be realise in the next 7 years by deducting the fiscal losses from the taxable profits.

For the above example, the profit tax $\left(\mathrm{T}_{\mathrm{p}}\right)$ due by the boarding house is:

$$
\mathrm{T}_{\mathrm{p}}=16 \% \times(50.000-30.000)=3.200 \mathrm{~m} . \mathrm{u} \text {. }
$$

\section{Case B) The boarding house is registered as a micro-enterprise}

The micro-enterprises do not pay the profit tax but the so-called tax on the incomes of microenterprises.

The conditions that must be fulfilled by an enterprise to be registered as a micro-enterprise are the following:

a) to obtain incomes that have not exceeded 100,000 euro;

b) the incomes must not to be obtained from the activities in fields like banking, insurance and re-insurance, gambling, consulting or management;

c) to have from 1 up to 9 employees including.

d) its capital shares to be owned by persons other than the state, local authorities, public institutions or entities with more than 250 employees.

The above conditions must be fulfilled on December $31^{\text {st }}$ of the previous fiscal year than that for which the taxpayer wants to apply this taxation system.

The tax on incomes of micro-enterprises is computed by applying a rate of $3 \%$ on registered incomes, except incomes from the production of assets for own necessities, subsidies, incomes from provisions, incomes from adjustments for depreciation or impairment losses and incomes from indemnifications granted by the insurance companies. The tax is computed quarterly on the incomes registered in respective quarter. For this reason, the tax regulation after the closing of the fiscal year is not necessary. The tax declaration and payment are settled on a quarterly basis on or before the $25^{\text {th }}$ of the month that follows the quarter for which the tax is computed. 
This is a simple system for taxation, facile and beneficial for taxpayer if the weight of expenses is reduced.

The tax on incomes of micro-enterprise in our example $\left(T_{\mathrm{im}}\right)$ is:

$$
\mathrm{T}_{\mathrm{im}}=3 \% \times 50.000=1.500 \text { m.u. }
$$

The Fiscal Code sets regulations regarding alternation of the taxation system, more precisely the passing to the profit taxation if one or more of the above conditions are no longer fulfilled.

\section{Case C) The boarding house's owner develops its economic activity as authorized natural person}

As natural person, the owner on the boarding house is due tax on receipts from rental with touristic purpose of the rooms placed in its personal house. The tax regulations in this case depend on the number of the rooms intended for rental.

If the boarding house has less of 5 rooms for tourist accommodation, the incomes are taxable as incomes from the grant of the use of goods. Otherwise, the incomes are taxable as incomes from independent activities.

In both situations the tax is calculated by applying the rate of $16 \%$ on annual net income. During the year the taxpayer is required to make anticipatory payments and after the determination of the taxable annual net income, the differences must be paid, if need be.

The annual net income may be determined on the basis of income norms or based on the simple entry accounting system (determination so-called "in real system").

Determination of net income on the basis of income norms

For certain economic activities developed by the natural persons, the General Directorates of Public Finance set the annual income norms for each administrative territorial unit. These differ from county to county, or from town to town. In rural areas the income norms are usually lower.

The annual tax is determined by the competent fiscal body by applying the tax rate of $16 \%$ to the income norm. The tax must be paid during the year in two equal rates, on or before July $25^{\text {th }}$, and November $25^{\text {th }}$ respectively.

Supposing that the boarding house in our example has an annual income norm of 12,000 m.u., the tax due by the natural person will be:

$$
\mathrm{T}_{\mathrm{i}}=16 \% \times 12.000=1.920 \text { m.u. }
$$

The natural person must submit only one tax declaration regarding the income norm, at the beginning of the year, on or before January $31^{\text {st }}$.

As a rule, if the natural person rents to the tourists less than 5 rooms, the annual net income is determined on the basis of income norms. If the natural person still wishes the determination of the net income based on the simple entry accounting system, he must submit a request with their option to the fiscal body.

\section{Determination of annual net income based on the simple entry accounting system}

The simple entry accounting is actually the cash accounting. The net income in this case is calculated as difference between the receipts and the paid deductible expenses during the fiscal year. The Fiscal Code establishes the conditions that the expenses must fulfil to be deductible for computation of the tax basis.

In case of application of the real system, the natural person is bound to submit a declaration at the beginning of the year, this time for estimated incomes and expenses, and to make anticipatory payments in two equal instalments (by July $25^{\text {th }}$ and November $25^{\text {th }}$ respectively). The value of the anticipatory payments is established by the competent fiscal body. After the fiscal year is closed, the natural person must declare the actual annual net income and, based on this statement, the fiscal body establishes the annual income tax and the differences to be paid or recovered. 
The rules presented for the determination of tax on natural person incomes are applicable in case of rental of villas too.

The Table 1 presents synthetically the rules for the taxation of boarding house incomes:

Table no.1. Rules for taxation of income from accommodation services

\begin{tabular}{|c|c|c|c|c|c|c|c|c|}
\hline \multirow{3}{*}{$\begin{array}{l}\text { Accommoda- } \\
\text { tion capacity }\end{array}$} & \multirow{2}{*}{\multicolumn{3}{|c|}{ Natural person }} & \multicolumn{5}{|c|}{ Legal person } \\
\hline & & & & \multirow{2}{*}{$\begin{array}{l}\text { Income } \\
\text { category }\end{array}$} & \multicolumn{2}{|c|}{ Profit tax payer } & \multicolumn{2}{|c|}{$\begin{array}{c}\text { Micro- } \\
\text { enterprise }\end{array}$} \\
\hline & $\begin{array}{l}\text { Income } \\
\text { category }\end{array}$ & Rate & $\mathrm{CB}^{*}$ & & Rate & $\mathrm{CB}^{*}$ & Rate & $\mathrm{CB}^{*}$ \\
\hline $1-5$ rooms & $\begin{array}{l}\text { Income } \\
\text { form the } \\
\text { grant of the } \\
\text { use of } \\
\text { goods }\end{array}$ & $16 \%$ & $\begin{array}{l}\text { Net } \\
\text { Income } \\
\text { (income } \\
\text { norms; } \\
\text { real } \\
\text { system, } \\
\text { optional) }\end{array}$ & \multirow{2}{*}{$\begin{array}{l}\text { Income } \\
\text { from } \\
\text { provision } \\
\text { of } \\
\text { services }\end{array}$} & \multirow[t]{2}{*}{$16 \%$} & \multirow{2}{*}{$\begin{array}{l}\text { Taxable } \\
\text { profit }\end{array}$} & \multirow[t]{2}{*}{$3 \%$} & \multirow{2}{*}{$\begin{array}{l}\text { Actual } \\
\text { income }\end{array}$} \\
\hline Over 5 rooms & $\begin{array}{l}\text { Income } \\
\text { from } \\
\text { independent } \\
\text { activities }\end{array}$ & $16 \%$ & $\begin{array}{l}\text { Net } \\
\text { Income } \\
\text { (income } \\
\text { norms or } \\
\text { real } \\
\text { system) } \\
\end{array}$ & & & & & \\
\hline
\end{tabular}

*CB - Computation basis

\section{Conclusions}

Considering the above, the boarding house' owner can optimize its fiscal duty if he estimates correctly the expenses necessary for business. Consequently, he can opt even for a taxation system influenced by the expenses, or for another one influenced only by the income. Also, he must consider the income norms established for the fiscal unit where his boarding house is registered.

A proper financial management allows the accommodation establishments' owners to apply lower tariffs for the services offered to the tourists. This is a very important aspect in gaining customers, especially foreign ones, in these current conditions of very high competitiveness.

\section{References}

1. Romanian Fiscal Code (2003), adopted by Law no. 571/2003, published in Official Gazette, Part I, no.927/23.12.2003, with subsequent amendments.

2. Durbarry, R., Sinclair, M.T. (2000), Tourism Taxation in the UK, available online at http://fama2.us.es:8080/turismo/turismonet1/

3. Dwyer, L., Forsyth, P., Papatheodorou, A. (2011), Economics of tourism, Contemporary Tourism Reviews, April 1, available at http://www.goodfellowpublishers.com/free files/fileEconomics.pdf

4. Eurostat (2011), Europe in figures - Eurostat Yearbook 2011, available online at http://epp.eurostat.ec.europa.eu/cache/ITY_OFFPUB/KS-CD-11-001/EN/KS-CD-11-001-EN.PDF

5. National Institute of Statistics (2010), Statistical Yearbook 2010, available online at http://www.insse.ro/cms/files/Anuar\%20statistic/20/20\%20Turism_ro.pdf

6. National Institute of Statistics (2012), Romanian Tourism - Statistical Abstract 2012, available online at www.insse.ro 